\title{
Od niepisanej umowy milczenia do protopolityczności: dyskursywny i sieciowy charakter społeczności osób homoseksualnych w „długich latach 70." w historii mówionej i epistolografii
}

\section{Tomasz Basiuk}

Uniwersytet Warszawski

\begin{abstract}
W Polsce podczas "dtugich lat 70." homoseksualność wkroczyła do języka publicznego i quasi-publicznego, umożliwiajac powstanie zrębów wspólnoty osób nie znających się bezpośrednio. Dyskursywne pojawienie się homoseksualności stopniowo zastępowało dotychczasowa niepisana umowę milczenia, zaś wczesne formy samoorganizacji były ściśle powiazane z sieciami prywatnych znajomości; protopolityczna towarzyskość wspierała i umożliwita pojawienie się właściwego aktywizmu. W rozdziale wykorzystano wywiady historii mówionej oraz listy nadestane przez mężczyzn z Polski do organizacji HOSI Wien w połowie lat 80. XX wieku.
\end{abstract}

Stowa kluczowe: protopolityczność, sieciowość, dyskursywność, historia mówiona, epistolografia, queer, przeszłość LGBT w Polsce

\section{Dyskursywny i sieciowy charakter społeczności homoseksualnej}

Prześledzenie na przestrzeni lat języka używanego do samookreślenia się lub do określenia innej osoby jako homoseksualisty, geja, lesbijki, pedała, pederasty, cioty, przedstawiciela mniejszości seksualnej, kogoś z branży, z naszego środowiska, koleżanki, jednego z naszych... itd. pozwala lepiej zrozumieć kryjące się za tymi terminami wyobrażenia. Dobór słów i towarzysząca mu refleksja odzwierciedlają proces wyodrębniania się i negocjowania grupowej tożsamości. Ważne są nie same słowa i ich konotacje (afirmujące, piętnujące, prześmiewcze...), lecz także ich pragmatyczny, dyskursywny obieg - kto używał poszczególnych zwrotów i określeń, do kogo je adresował i w jakich okolicznościach znajdowały zastosowanie. Niniejszy artykuł jest próbą naszkicowania fragmentarycznej mapy językowych uzusów w oparciu o wywiady historii mówionej dotyczące "długich lat 70." oraz listy wysłane z Polski do organizacji HOSI Wien w latach 80. XX wieku. ${ }^{1}$

Jednocześnie z wywiadów i epistolografii wyłania się szerszy obraz postępującej dyskursywizacji homoseksualności, polegającej na przełamywaniu niepisanej społecznej umowy milczenia na ten

${ }^{1}$ Tytułowe „długie lata 70." obejmują dekadę rządów Edwarda Gierka i Piotra Jaroszewicza oraz pierwszą połowę lat 80., to jest okres do Akcji „Hiacynt” (1985-1987), po której nastąpiła intensyfikacja aktywizmu lesbijek i gejów. Większość wykorzystanych w tekście wywiadów historii mówionej została przeprowadzona w ramach badania "Crusing the 1970s: unearthing pre-HIV/AIDS queer sexual cultures" (CRUSEV) przez Tomasza Basiuka i Krzysztofa Zabłockiego (oprócz jednego wywiadu przeprowadzonego tylko przez Tomasza Basiuka). Ponadto wykorzystano dwa wywiady nagrane na zlecenie Stowarzyszenia Lambda Warszawa i przeznaczone dla Domu Spotkań z Historią - wywiady te są zaznaczone w tekście. Materiały epistolograficzne pochodzą ze zbioru listów z Polski nadesłanych do wiedeńskiej organizacji HOSı Wien (Homosexuelle Initiative Wien) w latach 80. 
temat, przestrzeganej także przez osoby homoseksualne w obawie przed napiętnowaniem. ${ }^{2} \mathrm{~W}$ dwóch ostatnich dekadach PRL homoseksualność w coraz to większym stopniu funkcjonowała jako temat rozmów, a ich celem nie było wyłącznie zapoznanie seksualnych partnerów. Zmieniał się nie tylko sposób mówienia, ale cała sytuacja komunikacyjna.

Z dokonującą się przemianą językową wiąże się sieciowy charakter społeczności homoseksualnej. Homoseksualność była wielokrotnie opisywana w odniesieniu do przestrzeni, zwłaszcza miejskiej. Miejsca spotkań znane zainteresowanym - kawiarnie, bary, pikiety w parkach i publicznych toaletach - tworzą wirtualną, mentalną topografię, nałożoną na zwykłą przestrzeń miejską. ${ }^{3}$ Ale historie mówione i źródła epistolograficzne świadczą także o wirtualności wyznaczanej przez sieć powiązań czysto symbolicznych, nie mających bezpośredniego odbicia w przestrzeni fizycznej. Tworzyły ją relacje nawiązywane w obrębie homoseksualnej społeczności dzięki przekazywanym kontaktom, służące między innymi wymianie informacji i poglądów o nazywaniu i przedstawianiu homoseksualności w sferze publicznej.

Dyskursywizacja homoseksualności, polegająca na rozszerzeniu językowego obiegu i rosnącej refleksyjności, a także powiązany z nią sieciowy, wirtualny charakter homoseksualnej społeczności, miała w latach 70. charakter jednocześnie towarzyski i polityczny. Przekazanie telefonu do znajomych mogło być zachowaniem towarzyskim, podczas gdy wymiana listów na temat słownictwa stosowanego w samizdatowym wydawnictwie przeznaczonym dla homoseksualnych mężczyzn miała charakter polityczny. Jednak ścisłe rozdzielenie tych funkcji niezbyt dobrze oddaje dynamikę zdarzeń. Wytworzenie się wirtualnych sieci społecznościowych o charakterze towarzyskim i związane z tym rozszerzenie obiegu języka, w którym funkcjonowało pojęcie homoseksualności i inne powiązane pojęcia, były niezbędnym podłożem dla rodzącej się refleksyjności i wyłonienia się działań o charakterze politycznym. Funkcje towarzyskie i aktywistyczne nakładały się na siebie i bywały trudne do rozdzielenia. Z tych względów opisywane tu przemiany językowe i społecznościowe należałoby określić mianem "protopolitycznych", nawet jeśli aktorzy tych przemian nie zawsze zdawali sobie sprawę z rodzącej się perspektywy upublicznienia homoseksualności i możliwości wpisania jej w kontekst praw człowieka i praw obywatelskich.

2 Stosuję terminy "homoseksualista”, „osoba homoseksualna” oraz "homoseksualny, homoseksualna”, zaproponowane przez Jerzego Krzyszpienia (2018), a także "lesbijka”, chcąc podkreślić, że w latach 70. i wczesnych 80. nie funkcjonowało w polszczyźnie rozpowszechnione dziś słowo "gej”.

${ }^{3}$ Korzystający z pikiet posługują się swoistymi rytuałami - znaczącą wymianą spojrzeń, utartymi wyrażeniami służącymi do zakomunikowania zainteresowania, czy pozajęzykowymi gestami służącymi do negocjacji o charakterze seksualnym, których klasyczny opis dał Laud Humphreys. O homoseksualnej przestrzeni miejskiej Nowego Jorku pisał George Chauncey (1994), o Warszawie - Krzysztof Tomasik, Krzysztof Zabłocki i Marcin Piet (2009), a o sportetowanym przez Michała Witkowskiego w powieści Lubiewo Wrocławiu - Paulina Rogulska (2006). Szczególną rolę tych miejsc i panujących w nich obyczajów oddaje ukuty przez Michela Foucaulta neologizm „heterotopia”, oznaczający społeczną i przestrzenną niszę, w której realizuje się porządek odrębny od hegemonicznego (Foucault 1984). Społecznościowa geografia miasta uwzględniająca heterotopijne nisze funkcjonuje na zasadzie mentalnej, wirtualnej mapy nałożonej na zwykłą topografię przestrzeni. 
Mimo nieformalnych instytucji umożliwiających nawiązywanie kontaktów z partnerami tej samej płci, zwłaszcza w przypadku mężczyzn, powszechne milczenie na temat homoseksualności skutkowało ograniczeniem kontaktu do wymiaru fizycznego. Trudno było o zaangażowanie emocjonalne i budowanie trwałych więzi, zaś "kontakty homoseksualne były przypadkowe”, jak mówi jeden z rozmówców (ur. 1941). Przemiany, o których tu mowa, spowodowały, że przypadkowe kontakty stały się tylko jednym z możliwych scenariuszy, nie zagospodarowując całego horyzontu możliwości.

\section{Protopolityczne spektrum}

W latach 70. upolityczniona świadomość własnej seksualnej tożsamości, wspólnego politycznego interesu społeczności osób homoseksualnych (lub szerzej - osób seksualnie nienormatywnych) i ewentualnej rozbieżności interesów poszczególnych składowych tej społeczności stała się wyznacznikiem ruchu lesbijsko-gejowskiego w niektórych krajach na zachodzie Europy i w Ameryce Północnej. ${ }^{4} \mathrm{~W}$ wywiadzie udzielonym rozmówcom ze Stowarzyszenia Lambda Warszawa i przeznaczonym do zarchiwizowania w warszawskim Domu Spotkań z Historią przebywający w Warszawie w latach 1974-76 jako stypendysta Fulbrighta amerykańsko-kanadyjski historyk John Stanley (ur. 1949), wówczas doktorant, nie dostrzegał politycznego wymiaru ówczesnego życia polskiej społeczności homoseksualnej - które retroaktywnie nazywa życiem gejowskim - wskazując na nieistnienie jakiejkolwiek struktury organizacyjnej:

W latach 70. w Warszawie istniało towarzyskie życie gejowskie, ale nie było politycznej struktury organizacyjnej. Dlatego niewielkie grupki funkcjonowały w odrębnych światach. Nawiązywały między sobą relacje na przyjęciach i w lokalach. [tłum. aut.] $]^{5}$

Tezę tę łatwo potwierdzić przypominając, że pierwsze próby samoorganizacji społeczności homoseksualnej jako struktury politycznej pojawiły się po Akcji „Hiacynt”. ${ }^{6}$ Należy jednak zapytać o rodzącą się polityczną świadomość członków homoseksualnej społeczności i charakter kontaktów pomiędzy

4 PRL nie był całkowicie odizolowany od przemian obyczajowych dokonujących się po drugiej stronie żelaznej kurtyny. O transferach kulturowych między Polską a zagranicą w kontekście nienormatywnej seksualności pisze Łukasz Szulc (2018).

5 "Warsaw in the 1970s had a gay social life but there was no organized political structure. And as a result there were small groups that really lived in different domains. They had contact through organized parties but also through bars."

6 Pisze o tym Agata Fiedotow (2012). Inwigilacja osób homoseksualnych w ramach Akcji „Hiacynt” była odczuwana jako represyjna ze względu na swój skoordynowany i niemalże pokazowy charakter. Zatrzymania przeprowadzone jednocześnie w wielu różnych miejscach wytworzyły poczucie przynależności do grupy znajdującej się na celowniku władzy. Władza wysłała homoseksualistom sygnał, że skuteczne ukrywanie się nie jest możliwe. Jeden z rozmówców (ur. 1948) powiedział: "Akcja »Hiacynt« uświadomiła tym wszystkim ludziom, że jak najbardziej wszyscy o nich wiedzą". 19 listopada 1985 roku, kilka dni po pierwszej akcji, Waldemar Zboralski pisał w liście do Marka Jaworskiego (Andrzeja Selerowicza) z HOSI Wien: „Te bezprawne zatrzymania mają wprowadzić panikę? Chyba wprowadzą - ale wrogość kolejnej warstwy społeczeństwa przeciw komunistom w Polsce." Akcja podziałała jak katalizator, prowokując na przykład założenie w 1986 roku miesięcznika "Filo", wydawanego metodą powielaczową przez grupę skupioną wokół Ryszarda Kisiela, a także powstanie Warszawskiego Ruchu Homoseksualnego, założonego w 1987 roku przez grupę skupioną wokół Waldemara Zboralskiego, Sławomira Starosty i Krzysztofa Garwatowskiego, która podjęła nieudaną próbę zarejestrowania Ruchu w sądzie. 
"grupkami", o których mówi Stanley. Spotkania w lokalach i w innych publicznych miejscach, a także przyjęcia organizowane w prywatnych mieszkaniach były sposobem ujawniania się, jeśli nie przed światem zewnętrznym, to przed sobą nawzajem. ${ }^{7}$ Były też okazją do dzielenia się przemyśleniami i informacjami na temat upubliczniania się homoseksualności. Prasa od czasu do czasu donosiła o zagranicznych debatach na ten temat, a w 1974 roku w „Życiu Literackim” ukazał się pierwszy polski tekst publicystyczny napisany z perspektywy homoseksualnego mężczyzny. ${ }^{8}$

Na rodzącą się świadomość osób homoseksualnych jako grupy domagającej się uznania zwrócił uwagę seksuolog Zbigniew Lew-Starowicz, prowadzący rubrykę w „itd", w której odpowiadał na listy czytelników. W 1973 roku podał intrygujące dane:

4\% listów [z 1560 listów nadesłanych od 1969 do 1972] poświęconych jest tzw. zboczeniom seksualnym, chodzi tu przede wszystkim o homoseksualizm. Większość autorów tych listów domaga się "rehabilitacji” homoseksualizmu jako prawidłowej formy zaspokajania potrzeb seksualnych, część prosi o informacje co do przyczyn, objawów, następstw homoseksualizmu i innych form perwersyjnych. $\left(\right.$ "Listy do seksuologa [2]") ${ }^{9}$

Mimo uspakajającego dla dorozumianej heteronormatywnej większości dopisku o homoseksualności jako jednej z "form perwersyjnych", uderza niemalże wywrotowy wydźwięk podanej tu informacji. Po pierwsze, odsetek listów poświęconych homoseksualności oraz mniej rozpowszechnionym „zboczeniom seksualnym" odpowiadał upowszechnianym szacunkom liczebności tej grupy. Dzięki temu homoseksualność jawi się tu jako stały element populacji. Po drugie, mniejszość homoseksualna wypowiedziała się we własnej sprawie w odsetku odpowiadającym swojej domniemanej liczebności, a więc przynajmniej pisząc listy do seksuologa, nie była mniejszością milczącą. Po trzecie, większość tej grupy domagała się uznania swojej homoseksualności za pełnoprawną co najmniej w wymiarze naukowym. Chociaż Lew-Starowicz medykalizował to żądanie używając terminu "prawidłowa” zamiast pełnoprawna, a także pisząc o "rehabilitacji” (w sensie metaforycznym) zamiast o uznaniu, to jednak dokonał uderzającego leksykalnego wyboru pisząc "domaga się", ponieważ określenie to kojarzy się z żądaniem równouprawnienia lub innym żądaniem politycznym. Uderzający jest wreszcie czas, w którym opisywane listy powstały. Przełom lat 60. i 70. bardzo znacznie wyprzedza drugą

\footnotetext{
${ }^{7}$ W autobiografii The Motion of Light in Water Samuel R. Delany podkreśla wagę wzajemnej widoczności osób homoseksualnych dla wytworzenia się poczucia przynależności do grupy. Zob. też Basiuk (2013), ss. 123-128.

8 Przykładowo: W 1966 roku „Prawo i Życie” relacjonowało debatę na temat zniesienia kryminalizacji homoseksualizmu w Brytyjskiej Izbie Gmin, a także krótko omówiło sytuację osób homoseksualnych w kilku innych krajach (Zabrzeski). Latem 1970 r. „Forum" przedrukowało z francuskiego pisma satrycznego "Le Crapouillot” prześmiewczy artykuł "Pedemokracja czyli »Błękitna miłość«", którego bohaterami są między innymi "Światowa Organizacja Homosekualistów” i niemiecki aktywista Udo Erlenhardt. Cztery lata później w „Życiu Literackim” ukazał się manifest Tadeusza Gorgola „Homoseksualizm a opinia". Do wyszukania tych publikacji skorzystałem ze zbioru wycinków prasowych Telewizji Polskiej w Archiwum Akt Nowych, zebranych w teczce "Homoseksualizm" t. 1, sygn. 2/456.
}

${ }^{9}$ Dziękuję Agnieszce Kościańskiej za wskazanie i udostępnienie wycinków z „itd." 
połowę lat 80., uznawaną za początek politycznej samoorganizacji społeczności lesbijsko-gejowskiej. Wyprzedza także okres wspominany przez Stanleya, który nie odnotował przejawów politycznej świadomości w życiu gejowskim, w jakim uczestniczył podczas pobytu w Warszawie w połowie lat 70.

Listy, o których pisał Lew-Starowicz, nie zachowały się. Nie można wykluczyć, że przynajmniej część z nich - cztery procent nadesłanej korespondencji to zapewne około 70 listów - była bardziej stonowana, niż nakreślił to adresat, opisując je grosso modo. Nie sposób jednak całkiem odżegnywać się od myśli, że obserwacje Stanleya i Lwa-Starowicza stanowią umowne krańce spektrum, pomiędzy którymi już w pierwszej połowie lat 70. rozgrywał się proces dochodzenia do grupowej samoświadomości, zapowiadający późniejszy aktywizm.

\section{Milczenie wokół homoseksualności}

W wywiadach często pojawia się przekonanie, że homoseksualność w Polsce była na tyle stabuizowana, że panowała swoista zmowa milczenia w tej sprawie. Mimo (dość nielicznych) publikacji prasowych na ten temat, zawoalowanych aluzji literackich i pewnej liczby przekładów literatury obcej, a także okazjonalnego, zwykle prześmiewczego ukazywania homoseksualności na ekranie, rozmówcy często są zdania, że o tych rzeczach nie mówiło się. ${ }^{10} \mathrm{~W} 1993$ roku tę społeczną umowę milczenia przywołał w tytule głośnego autobiograficznego opowiadania Julian Stryjkowski. Milczenie wokół homoseksualności można rozumieć jako pochodną milczenia państwa. Wzorowane na Kodeksie Napoleona pominięcie homoseksualności w pierwszym porozbiorowym kodeksie kryminalnym z 1932 roku ustanowiło standard oficjalnej neutralności i obojętności, a jednocześnie usunęło podstawową motywację do podejmowania działań na rzecz równości praw, jaką w wielu innych krajach było dążenie do dekryminalizacji kontaktów homoseksualnych.

Powszechne milczenie przekładało się na osobiste doświadczenia. Niezwykle uderzająca jest relacja Elżbiety Parczewskiej (ur. 1951), która opowiedziała swoją historię rozmówcom ze Stowarzyszenia Lambda Warszawa (z przeznaczeniem dla Domu Spotkań z Historią). Kobieta ta wyjechała z Polski do Stanów Zjednoczonych w roku 1980 i zawarła tam związek małżeński. Po pewnym czasie poznała kobietę, z którą związała się na parędziesiąt lat, rozstając się z tego powodu z (drugim) mężem, który zresztą odniósł się do decyzji żony ze zrozumieniem. ${ }^{11}$ Trajektoria opowiadającej pokazuje, że znalezienie się w społeczeństwie, w którym homoseksualność jest rozpoznawalna jako równoprawny wybór umożliwiło jej nie tylko realizację, lecz także jasne uświadomienie odczuwanych już wcześniej

\footnotetext{
10 O sposobach mówienia i niemówienia o homoseksualności w literaturze i filmie piszą na przykład German Ritz (2002), Błażej Warkocki (2007), Sebastian Jagielski (2013), Małgorzata Sadowska i Bartosz Żurawiecki (2006), a także Krzysztof Tomasik $(2012 ; 2018)$

${ }^{11}$ Elżebieta Parczewska przekazała Bibliotece Stowarzyszenia Lambda Warszawa kilka egzemplarzy wspomnień autorstwa swojej partnerki Lynn S. French, wydanych pośmiertnie przez Parczewską w formie zeszytu pod tytułem Memories. Forbitten Love [sic.].
} 
pragnień. Jej wcześniejsze, polskie perypetie, opowiedziane retrospektywnie nabierają niemalże komicznego charakteru. Jako osoba dorosła, wykształcona, mieszkająca w Warszawie i zatrudniona w dużej państwowej instytucji była zauroczona koleżanką z biura, pisała do niej listy i obsypywała ją drobnymi podarkami. Tracąc cierpliwość, koleżanka złożyła skargę, w wyniku której opowiadająca została zwolniona z pracy. Choć słowo "homoseksualizm" nie padło, przełożony dał jej do zrozumienia, że powodem zwolnienia było jej zachowanie wobec koleżanki. Mimo tych poważnych konsekwencji kobieta ani nie postrzegała swojego zachowania jako stalkingu, ani nawet nie rozumiała, że zakochała się w innej kobiecie, uważając ją po prostu za ulubioną przyjaciółkę. Jest to o tyle zaskakujące, że opowiadająca pochodzi z profesorskiej rodziny, a istnienie seksualnych odmienności było jej teoretycznie znane. Kiedy podczas towarzyskiego spotkania opowiedziała o swoich kłopotach w pracy znajomemu seksuologowi, ten powiedział jej wprost, że jest "zboczona”, na co ona zareagowała pustym śmiechem, nie dopuszczając myśli, że jej pragnienie może być skierowane na inną kobietę.

Mechanizm obronny uniemożliwiający uświadomienie sobie własnych homoseksualnych skłonności można postrzegać jako uwewnętrznienie powszechnej umowy milczenia. Zmiana sposobu postrzegania samej siebie zajęła opowiadającej powyższą historię wiele lat i dokonała się dopiero po wyjeździe z kraju, który wymusił osłabienie kontaktów z dotychczasowym otoczeniem i umieścił ją w środowisku, w którym własna homoseksualność stała się dla niej możliwa do wyobrażenia, ponieważ była wyobrażalna dla bliskich jej osób. Wyjeżdżając w 1980 roku do Stanów Zjednoczonych kobieta znalazła się w społeczeństwie, w którym nie obowiązywała równie silna, co w Polsce, tabuizacja homoseksualności.

\section{Milczenie w rodzinie}

W wywiadach historii mówionej przeprowadzonych w ramach badania "Cruising the 1970s: unearthing pre-HIV/AIDS queer sexual cultures" (CRUSEV) rozmówcy często wspominają o przeważnie niewyartykułowanym oczekiwaniu ze strony rodziny pochodzenia dotyczącym wejścia w (heteroseksualny) związek małżeński i założenia własnej tradycyjnej rodziny. Oczekiwanie to wydaje się w pierwszym rzędzie motywowane domniemaniem heteronormatywności, a nie homofobią rozumianą jako struktura afektywna (niechęć do homoseksualizmu), choć w jednej z historii ważną rolę odgrywa poczucie wstydu. Brak artykulacji heteronormatywnych oczekiwań wynikał z tabuizacji homoseksualności - po prostu nie było o czym mówić, skoro perspektywa zreprodukowania heteroseksualnych wzorców jawiła się jako oczywista. Poczucie braku alternatywy było internalizowane przez rozmówczynie i rozmówców, którzy przynajmniej do pewnego momentu realizowali ten wzorzec, mimo odczuwanego pociągu do własnej płci. Ci zaś, którzy wyłamali się z tego oczekiwania i żyli w związkach z osobami tej samej płci, często wyrażają przekonanie, że milczenie na temat homoseksualności było (i nadal jest) formą niepisanego kompromisu zawieranego z bliskimi - z rodzicami, ale także z własnymi dziećmi - dzięki któremu partnerka lub partner funkcjonuje jako członek rodziny, a jednocześnie jej lub jego społeczna rola pozostaje nienazwana. 
Sarah Schulman opisuje homofobię w rodzinach jako przemożne, choć stosunkowo rzadko opisywane zjawisko wpływające na życie osób nieheteronormatywnych. W relacjach rozmówców nie pojawiają się przypadki fizycznej ani werbalnej przemocy wobec nich ze strony członków rodziny. Należy jednak pamiętać, że nie badaliśmy próby losowej, lecz stosowaliśmy metodę kuli śnieżnej, właściwą do badań jakościowych - nasza próba nie jest więc reprezentatywna w sensie statystycznym. Pojawiają się natomiast co najmniej trzy warianty scenariusza stosunku rodziny pochodzenia do homoseksualności jej członka.

Pierwszy scenariusz dotyczy sytuacji rzeczywistej lub domniemanej niewiedzy. Rozmówca (ur. 1949) uważa, że rodzice - w tym przypadku osoby niewykształcone - nie byliby w stanie dostrzec ani nawet pojąć homoseksualności syna, ponieważ taka możliwość wcale nie mogłaby przyjść im do głowy. „Ojciec i matka ludzie bardzo prości, bardzo dobrzy, twardzi życiowo, z gór, i tak dalej, ale z wyobraźnią na bakier i z wykształceniem też. To zupełnie co innego. Oni nie musieli nic wypierać. Oni nie mieli tego w świadomości." Przekonanie rozmówcy, który porównuje ze sobą nastawienie poszczególnych osób w swojej rodzinie pochodzenia, nie opiera się na konkretnym wydarzeniu. Niemniej rozmówca jest zdania, że społeczna umowa milczenia z pewnością usunęła homoseksualność poza horyzont poznawczy jego rodziców jako osób ze starszego pokolenia i słabo wykształconych - nie na zasadzie wyparcia, lecz z powodu niewiedzy, a więc braku wzorców kulturowych wskazujących na taką możliwość.

Drugi scenariusz, niewykluczający poprzedniego, to silna i zwykle uwewnętrzniona presja rodziny pochodzenia i szerszych oczekiwań społecznych na powielenie powszechnego modelu, polegającego na wstąpieniu w związek małżeński i posiadaniu dzieci. Tego rodzaju presja, która w naszych wywiadach dotyczy zarówno kobiet, jak i mężczyzn, przypomina opisywany przez Adrienne Rich i odniesiony przez nią do doświadczenia kobiet "przymus heteroseksualności” (compulsive heterosexuality), oznaczający usunięcie z horyzontu własnych wyobrażeń o sobie trajektorii obejmującej związek homoseksualny. Rozmówca (ur. 1958) uległ tej uwewnętrznionej presji mimo świadomości erotycznego zainteresowania mężczyznami, ponieważ nie wyobrażał sobie innej drogi życiowej:

Było to na zasadzie tak, że, że, że jakby... byłem ja, o czym tylko ja wiedziałem sam w sobie i było to takie jakby... ten wzorzec narzucony przez rodzinę, przez, przez jakieś społeczne wzorce, które wiedziałem, że muszę przyjąć. No bo tak wszyscy wtedy je przyjmowali, bo nie było specjalnie, nie miałem żadnego, nigdzie, żadnego przykładu dookoła, który by świadczył, że można, można postąpić inaczej, można zrobić inaczej [...] bo powinno się założyć rodzinę, bo ojciec założył rodzinę, bo dookoła wszyscy zakładali rodziny. No więc ja też założyłem rodzinę.

Rozmówca ożenił się i żył w małżeństwie przez ponad dwadzieścia lat, wychowując razem z żoną adoptowane dziecko. Realizował heteroseksualny wzorzec społeczny w sposób niemal bezrefleksyjny, nie widząc dla siebie alternatywy mimo świadomości własnych potrzeb homoseksualnych, 
które zaczął realizować dopiero po dłuższym czasie. Jego małżeństwo zakończyło się rozwodem na żądanie żony, która dowiedziała się o jego związku z mężczyzną.

Trzeci scenariusz dotyczy osób, które wyłamały się z oczekiwania heteroseksualnego związku, lecz zawarły niepisany kompromis - rodzina pochodzenia utrzymywała kontakty z partnerką lub partnerem, lecz o związku nie mówiło się wprost. Mężczyzna (lat ok. 70), który przedtem ożenił się i rozwiódł, opowiada, że on i jego partner byli zapraszani przez jednych i drugich rodziców, którzy zresztą także się poznali, a mimo to relacja ich synów pozostała nienazwana:

Poznałem chłopaka, z którym my byliśmy naście lat. [...] nie rozmawiało się na żaden temat w ogóle. Ale oczywiście byłem zapraszany. Zapraszany do jego rodziny. Jego rodzina miała działkę [...], myśmy tam spędzali czas jakiś dłuższy i tak dalej. Czy święta tak samo. I później odwrotna sytuacja była tak i również. [...] Nawet wręcz, że... Nasi rodzice się tu, gdzieś, coś tam, spotkali po prostu tak. Przy okazji jakichś tam imienin, czy czegoś, już tego dokładnie nie pamiętam... [...] To było takie, trochę niby jesteśmy kolegami, ale...

Obie rodziny pochodzenia milcząco akceptowały związek synów, jednak warunkiem niewypowiedzianego uznania było obustronne milczenie na temat rzeczywistego statusu partnera.

Historia kobiety (lat ok. 70) wpisuje się w scenariusze drugi i trzeci. Rozmówczyni zawarła ślub, mimo że od wczesnej młodości zakochiwała się w nauczycielce i koleżankach, zaś w szkole średniej, mieszkając w internacie, a potem na stancji, była w seksualnym związku z dziewczyną. Po studiach, w trakcie których powstrzymywała się od nawiązywania jakichkolwiek intymnych relacji, została skierowana na terapię grupową zorientowaną na leczenie nerwic, gdzie poznała swojego przyszłego męża. Wyszła za niego pomimo świadomości swojej seksualnej odmienności, z którą nie umiała się pogodzić:

Kontakty fizyczne z mężczyzną to było dla mnie coś nienaturalnego. [...] Ponieważ mi samej zależało nie być taką jakby, no nie umiałam się z tym pogodzić, [...] bałam się tego odrzucenia, bałam się takiego ostracyzmu społecznego... Trochę taki wstyd. No, ale ponieważ tam w miarę mogłam być, no jakoś tam szczera [...], więc to tak trochę spadło to ciśnienie ze mnie i tam poznałam też takiego chłopaka. [...] No jakoś tam się zbliżyliśmy do siebie, on jakoś tak do mnie przylgnął i jakoś potrzebował mnie, ja też się poczułam jakaś taka ważna dla niego, i po prostu wyszłam za niego za mąż. [...] Oczywiście z tym moim mężem, który jakby wiedział, no bo był ze mną [na terapii - przyp. aut.], [...] nigdy o tym nie rozmawialiśmy, bo to jakby wyglądało, że się wyleczyłam, czy coś w tym stylu. No sama przed sobą jakby to udawałam. 
Dla zrozumienia, dlaczego rozmówczyni „po prostu” wyszła za mąż znacząca jest wzmianka o wstydzie, która wskazuje na psychologiczny mechanizm uwewnętrznienia społecznego tabu - wstyd funkcjonuje jako sankcja i wpływa na zachowanie nawet wtedy, gdy zakaz nie jest wprost wyartykułowany. ${ }^{12}$ Znamienne jest wieloletnie milczenie małżonków o homoseksualności kobiety, której przecież oboje są świadomi. (Analogiczne milczenie cechowało wielotygodniowy proces grupowej terapii, podczas której się poznali, mimo że rozmówczyni już na wstępie jednoznacznie zadeklarowała swoje homoseksualne skłonności.)

Rozmówczyni trwała w małżeństwie około dwudziestu lat, wychowując dwóch synów. Mimo pozorów rodzinnego szczęścia musiała aktywnie unikać towarzystwa kobiet, żeby się w nich nie zakochiwać. W wieku prawie pięćdziesięciu lat poznała inną kobietę, z którą na pewien czas się związała. Następnie spotykała kolejne, dzięki temu, że pod koniec lat 90. istniały już kluby, w których kobiety mogły poznawać kobiety. Rozstała się z mężem i związała się ze swoją aktualną partnerką, z którą jest razem od prawie dwudziestu lat.

Rozmówczyni zwraca uwagę na różnice w widoczności homoseksualnych kobiet i mężczyzn. Podczas gdy męska homoseksualność jest stosunkowo widoczna, lesbijki pozostają nieczytelne:

Homoseksualność mężczyzn, nawet jeżeli była właśnie przedmiotem drwin i powodem ostracyzmu i tak dalej [...] jednak była widoczna, to znaczy, że jeżeli ktoś chodził do parku i tam się spotykał, to zostało jakoś tam zauważone, to o tym można było mówić i się mówiło, nawet jeżeli się mówiło bardzo pejoratywnie, to jednak się mówiło. Natomiast ja pamiętam, że słowo "pedał" się pojawiało w moim dzieciństwie, prawda? I że ktoś powiedział "A tamten to jest pedał" czy coś takiego. Natomiast praktycznie rzecz biorąc, nie pamiętam, żeby cokolwiek takiego, żebym cokolwiek takiego słyszała o kobietach czy o dziewczynach. A jeżeli, to rzadziej. [...] Tak jak ci powiedziałam o tej mojej przyjaciółce jednej, której powiedziałam, że się bardzo w niej kochałam, a jej w ogóle by do głowy to nie przyszło, że mogło coś takiego być ze mną i w ogóle. Że ludzie jakby wiesz, że nam się wydaje, że to jest takie czytelne, jawne i oczywiste, a dla innych może nie nawet.

Rozmówczyni i jej partnerka utrzymują relacje zarówno z byłym mężem, jak i z dziećmi pierwszej z nich. Nie znaczy to jednak, że tabu homoseksualności zniknęło. Rozmówczyni napotyka na sprzeciw, gdy chce porozmawiać z dorosłym synem o swoim wieloletnim związku z kobietą. Syn zna partnerkę matki od dawna i miał szereg okazji, by zauważyć, że kobiety współdzielą łóżko. Niechęć swojego syna, który założył własną rodzinę, do skonfrontowania się z jej homoseksualnością postrzega jako

12 O wstydzie jako mechanizmie kontroli społecznej zob. Basiuk (2013), ss. 49; 160-161; passim. 
efekt obawy przed społecznym piętnem - ponownie więc zwraca uwagę na rolę wstydu, choć tym razem nie używa tego słowa:

O coming oucie chcę powiedzieć. To znaczy było takie coś, że troszkę mi to ciążyło, że ja nigdy nie porozmawiałam o tym z moimi synami w sposób otwarty. Raz nawet próbowałam z tym starszym i właśnie tam zaczęłam: wiesz, [...] chciałabym ci coś tam powiedzieć... A on do mnie tak krótko i węzłowato: mamusia, nie jestem ciekawy. [...] Nie wiem, na ile oni mówią swoim znajomym. Myślę, że nie. Może. Nie wiem. A jeśli mówią, to w tajemnicy.

Milczenie w rodzinie, wynikające z napiętnowania homoseksualności i związanego z tym uczucia wstydu funkcjonuje nadal, mimo że zbiór wyobrażalnych trajektorii życiowych obejmuje dziś związek osób tej samej płci.

Rozmówczyni uważa, że relacja homoseksualnego rodzica z dziećmi jest inna - domyślnie: trudniejsza, mniej społecznie rozpoznana - niż odwrotna relacja rodzica z homoseksualnym dzieckiem. „Inaczej jest, jeśli to są, jeśli to jest matka i dzieci, są osobami, są właśnie gejami i lesbijkami, a inaczej jest w drugą stronę..."

Omówione scenariusze milczenia w rodzinie oparte są na autentycznej niewiedzy, na zinternalizowanych wzorcach heteronormatywności oraz na uznaniu partnerki lub partnera, którego niepisanym warunkiem jest nienazwany charakter homoseksualnego związku dziecka lub rodzica. Scenariusze te funkcjonują zarówno w przypadku kobiet, jak i mężczyzn. Jednocześnie cytowana rozmówczyni podkreśla, że homoseksualność kobiet jest trudniejsza do zauważenia, niż homoseksualność mężczyzn, która częściej bywa otwarcie napiętnowana.

\section{Udział języka w nawiązywaniu wczesnych kontaktów homoseksualnych przez mężczyzn}

Historie mówione mężczyzn (liczniejsze w badaniu niż historie kobiet) pozwalają zrozumieć działanie tabuizacji homoseksualności w osobistym doświadczeniu, a jednocześnie ukazują stopniowe luzowanie niepisanego zakazu mówienia na ten temat. Przytoczone poniżej anegdoty dotyczą nawiązywania kontaktów z innymi mężczyznami i wskazują na rosnącą rolę informacji werbalnej w podejmowaniu aktywności seksualnej. Wszystkie opisane zdarzenia miały miejsce w Warszawie na przestrzeni około dwóch dekad. Każdy z rozmówców opowiada o czymś, co przydarzyło mu się w wieku około czternastu lat, lecz pierwszy z nich mówi o latach 50., drugi - o latach 60., a trzeci - o latach 70. W pierwszej historii dominuje kontakt niewerbalny, w drugiej kontakt werbalny służy uwiedzeniu i jednocześnie zaprzecza homoseksualnemu charakterowi spotkania, w trzeciej kontakt werbalny służy pozyskaniu użytecznej informacji w przypadkowej rozmowie dotyczącej homoseksualności. Mimo idiosynkratycznych różnic między opowiadającymi i między zrelacjonowanymi przez nich wydarzeniami, historie te wskazują na stopniowe udyskursowienie homoseksualności. 
Relacja pierwszego mężczyzny (lat 80) dotyczy lat 50. Mężczyzna uczęszczał wówczas do gimnazjum na Saskiej Kępie:

Pierwsze moje doznanie było niesamowite, bo to się zaczęło jeszcze w gimnazjum i liceum. Był taki przedmiot: przysposobienie wojskowe [...] Nie zapomnę, że poszliśmy na jakieś strzelania [...] i sytuacja się stała na tyle dla mnie zaskakująca, a jednocześnie potem pociągnęła za sobą ciekawość dalej, bo, bo w czasie tego strzelania gdzieś tam oddaliłem się za potrzebą fizjologiczną i niespodziewanie stanął obok mnie, nazwijmy to, profesor przysposobienia wojskowego i stało, tak jak się stało, po prostu złapał mnie w czasie, że tak powiem, siusiania, za ciołka i ja... nie wiedziałem jak się mam zachować, ale [...] to jak gdyby był początek moich potem zachowań, sam wobec siebie poczułem jak gdyby, że widocznie tak będzie, tak się potoczy to dalej, bo następna historia, jaka powiedzmy tam, w pewnym okresie czasu zdarzyła mi się - w środku komunikacji miejskiej. Ja jechałem gdzieś w tłoku, w tramwaju i poczułem, że ktoś się tam w jakiś sposób, jak to się mówi popularnie, dobiera, prawda? No więc też, konsternacja, bo nie wiem, [...] wysiąść, nie wysiąść? Ja jechałem zupełnie gdzieś indziej i, ale..., ale tam że, zobaczymy, co z tego wyjdzie, jak to się rozwinie, co się stanie, prawda?

Inicjacja seksualna podczas zajęć nad Wisłą i kolejne uwiedzenie w tramwaju utwierdziły młodego chłopaka w przekonaniu, że interesują go mężczyźni. Oba kontakty były zainicjowane przez innych mężczyzn bez użycia słów. Dopiero później, poznając w ten sposób kolejne osoby, rozmówca dowiedział się o istnieniu miejsc, do których może się udać w celu nawiązania znajomości z innymi mężczyznami. Opisane przez niego doświadczenia wydają się charakterystyczne dla kontekstu, w którym homoseksualność jest na tyle mocno stabuizowana, że spotkanie prowadzące do kontaktu seksualnego odbywa się w milczeniu, a ewentualna szczera rozmowa o homoseksualności jest możliwa jedynie między osobami, które już rozpoznały się wzajemnie jako homoseksualne.

Młodszy o dekadę rozmówca (lat ok. 70) od około dziesiątego roku życia był regularnie molestowany przez starszego o sześć lat przyrodniego brata - obaj z bratem spali razem ze względu na ciasnotę w mieszkaniu. Kilka lat później rozmówca podjął dość nieporadną próbę znalezienia partnerki seksualnej, w efekcie czego został uwiedziony przez mężczyznę (działającego pospołu z innym mężczyzną):

...ja, tak mówiąc szczerze, to ja jestem gejem, może i cechy są, ale mój brat mnie demoralizował od dziecka starszy i ja po prostu wzrastałem w tym. Ale chciałem poznać jakąś dziewczynę, też mnie poznał jakiś pedofil, uwiódł mnie, to pierwsze moje kontakty [...] wybrałem się na Zieleniecką, tam było wesołe miasteczko, bo mnie koledzy powiedzieli, że tam przychodzą dziewczyny, to poznasz i sobie wyruchasz ją. O, kiedyś się mówiło wyruchasz. Nie wybzykasz, tylko wyruchasz. No i poszedłem tam. Pochodziłem, pochodziłem, ale nic tak się nie trafiała żadna do 
wyruchania za przeproszeniem. I tam też była taka blaszanka. Bo takich jak na placu Trzech Krzyży, to było dużo, dużo więcej. Była na Zielenieckiej właśnie. [...] No i wszedłem żeby się załatwić do tego takiego okrąglaka, jak na placu Trzech Krzyży. [...] No i wychylił się i mnie pokazał, prowokował. I ja, no przecież doświadczenia nie miałem, i wstydliwy wyszedłem z tego. I tak zacząłem tam chodzić. A on doszedł ze znajomym swoim [...] zaczęli mi tam opowiadać o dziewczynach, to. Że wiesz, bo co ja robię? To mówiłem, że przyszedłem, żeby zarwać jakąś dziewczynę, że to. No i ten temat mnie podniecił widocznie, że nie zorientowałem się, jak on mnie do buzi wziął, no.

Uwiedzenie nastąpiło pod pretekstem zainteresowania kontaktem heteroseksualnym - komunikat werbalny był właściwie kamuflażem skrywającym homoseksualny charakter nawiązywanej relacji. Rozmowa o dziewczynach była zapewne taktycznym wybiegiem ze strony uwodzicieli, a z drugiej strony pozwoliła młodemu chłopakowi skryć się za społecznie akceptowanym pragnieniem heteroseksualnym.

Po tym wydarzeniu wielokrotnie powracał na Zieleniecką, wynajdując partnerów do seksu oralnego: „...mnie nie interesował później facet jako facet, tylko żeby mnie dobrze laskę robił. Patrzyłem, czy ma mięsiste usta, czy mi dobrze laskę zrobi". Przy tych kolejnych kontaktach komunikat werbalny nie wydawał się ważny, a usta nie służyły do mówienia.

Nastawienie rozmówcy zmieniło się jednak pod wpływem jednego z napotkanych mężczyzn, który zabrał go w bardziej ustronne miejsce, okazując czułość:

No, aż wreszcie trafiłem po jakimś czasie na jakiegoś oficera takiego, miał dwadzieścia osiem lat. I on mnie uświadomił dopiero o tym życiu. I wziął mnie do parku, tam bliżej Teatru Powszechnego. Tam jest teraz restauracja i taki hotel, ale był taki stóg siana jak gdyby. On tam wiedział, że tam można iść, tam mnie wziął. I tam zaczął mnie pieścić i chciał się całować ze mną. I ja sobie myślałem, że on jakiś nienormalny. Żeby z facetem? Dlatego mówię, że człowiek tą taką ewolucję przechodzi psychiczną.

Ewolucja psychiczna polegała na wyjściu poza prostą przyjemność seksualną i na nawiązaniu kontaktu wskazującego na możliwość pożądania partnera tej samej płci, a nie tylko posiadacza "mięsistych ust" albo kogoś gotowego porozmawiać o tym, jak nastolatek mógłby „zarwać jakąś dziewczynę". Jednocześnie ewolucja rozmówcy wskazuje na nawiązanie kontaktu werbalnego - poznany oficer wprowadził rozmówcę w rejestr wyrażania uczuć („zaczął mnie pieścić i chciał się całować ze mną") i pomógł odkryć, że homoseksualność może być czymś więcej, niż przygodną przyjemnością („on mnie uświadomił dopiero o tym życiu”). 
Kolejny rozmówca (ur. 1960), świadomy swojego zainteresowania mężczyznami ze względu na wcześniejszy kontakt homoseksualny, w połowie lat 70. usłyszał od szkolnych kolegów, że "pedały” spotykają się w miejskiej saunie i postanowił sprawdzić tę informację (wymienia łaźnię Centralną, czyli Messalkę na Krakowskim Przedmieściu, Dianę przy ul. Rutkowskiego [obecnie Chmielna], a także łaźnię na placu Starynkiewicza i łaźnię na Stegnach). W ten sposób trafił w miejsce, w którym mógł znaleźć partnerów seksualnych. Jego zdaniem informacja o miejscach spotkań homoseksualistów krążyła szeroko, skoro powtarzali ją nawet szkolni koledzy, którzy sami niekoniecznie zetknęli się z takim zachowaniem:

To... funkcjonowało, jak się potem okazywało, to ja się dowiedziałem od kolegów ze szkoły, no skąd, skąd... chłopak ze szkoły mający czternaście lat no rzucił tak? Że tam się pedały spotykają, to skąd on mógł wiedzieć? [...] No... wszyscy wiedzieli o tym, a... to wyszło tak jakby niejako przypadkowo. I ja z tego skorzystałem. Poszedłem i zobaczyłem, że faktycznie, i że jest fajnie także, także. Natomiast to... potem się okazało, że to funkcjonowało normalnie, wszyscy wiedzieli, że, że w łaźniach i tak dalej. I wszyscy wiedzieli, że na... że na dworcu, prawda? Czy że tam, prawda, w paru innych miejscach także...

Każda z tych trzech opowieści jest nieco inna. Mężczyzna urodzony w drugiej połowie lat 30. Przeszedł inicjację w latach 50. Odbyło się to bez słów i bez jego inicjatywy, w sposób dla niego niespodziewany. Podobnie wyglądał jego kolejny kontakt (spotkanie w tramwaju). Inicjacja młodszego o dekadę mężczyzny - jeśli nie liczyć molestowania przez starszego brata - miała miejsce w latach 60. i wydarzyła się pod pretekstem rozmowy o dziewczynach, podczas której został uwiedziony. Kolejne kontakty seksualne nie wymagały rozmowy, dopóki nie poznał kogoś, kto zaangażował się w tę znajomość uczuciowo. Natomiast doświadczenie najmłodszego z mężczyzn, w połowie lat 70., odbyło się z inicjatywy rozmówcy, który w przypadkowej rozmowie dowiedział się o miejscach nawiązywania kontaktów między mężczyznami. Choć przekazana informacja miała zapewne wydźwięk skandalizujący, to była na tyle konkretna, że pozwoliła mu trafić pod właściwy adres. Tylko ostatni rozmówca funkcjonował w kontekście komunikacyjnym, w którym o homoseksualności mówiło się w sposób w miarę otwarty.

\section{Od towarzyskości do społeczności}

Jeśli postępująca dyskursywizacja homoseksualności odróżnia lata 70. od wcześniejszych dekad, to uwaga Johna Stanleya - "W latach 70. w Warszawie istniało towarzyskie życie gejowskie..." [a gay social life] - wskazuje na rodzące się poczucie przynależności do grupy, a określenie "social" nabiera szerszego znaczenia niż „towarzyskie”, sugerując wyłaniające się poczucie społeczności rozumianej jako wspólnota losów, interesów i zainteresowań. Mimo że brakowało struktur stricte organizacyjnych, rodziła się sieć społecznych powiązań opartych na kontakcie werbalnym. 
W relacjach rozmówców wielokrotnie pojawia się wspomnienie łatwości, z jaką nawiązywano kontakty z polecenia znajomych. Mężczyzna (lat 80) przedstawia sieć towarzyskich powiązań jako swoisty ekwiwalent aktywizmu, któremu nie sprzyjały okoliczności polityczne:

I cofając się do tamtego czasu, no to tylko można żałować, że tak nie było, ale nie mieliśmy na to żadnego wpływu, takie były czasy, taki był system i niczego oczekiwać nie było można, dlatego że, że co? Mogliśmy stanąć na barykadzie i co, pomachać flagą? Nie było takiej możliwości, natomiast samo to że, że jakoś ten krąg się ludzi ciągle powiększał, powiedzmy, Andrzej poznał Tadeusza, Tadeusz poznał Romka, Romek poznał Zbyszka i to potem wszystko gdzieś...

Niedokończone zdanie wskazuje na przyszłe skutki towarzyskich kontaktów, które z czasem umożliwiły inne działania, także te o charakterze politycznym.

Kontaktowano nowo poznanych z osobami, z którymi mogli się spotkać przy okazji podróży do innego miasta, a nawet u nich zatrzymać. Był to z pewnością obyczaj nie tylko społeczności homoseksualnej, lecz bardziej powszechny sposób funkcjonowania zwłaszcza młodych ludzi. Niemniej zwyczaj ten sprzyjał rozwojowi sieci powiązań między osobami homoseksualnymi. Mężczyzna (lat 75), który przyjechał do Polski na studia z NRD, opowiada o swoich doświadczeniach na przełomie lat 60. i 70.: "No ja po prostu, po prostu przecież wszędzie musiałem gdzieś nocować. No i jak nocowałem to się za każdym razem okazało, że z nimi można się... puścić. To było niesamowite w ogóle. Ja myślałem, że w stu procentach młodzież jest tutaj gejowska". Najwyraźniej rozmówca miał powodzenie u mężczyzn, niemniej jego wypowiedź wskazuje na rozpowszechniony sposób nawiązywania znajomości na zasadzie polecenia, zasadniczo odmienny od wcześniejszego schematu anonimowych kontaktów seksualnych. Sieciowy charakter rodzącej się homoseksualnej społeczności uzupełniał i częściowo wypierał działające jeszcze przed epoką PRL nieformalne instytucje, takie jak łaźnie i pikiety. O ile część rozmówców korzystała z tych miejsc i jednocześnie brała udział w przełamującym anonimowość życiu towarzyskim, to inna część nawiązywała kontakty jedynie na przyjęciach i przez znajomych, podkreślając w wywiadach, że w ten sposób unikała narażania się na niebezpieczeństwo związane z anonimowymi kontaktami - chodziło głównie o kradzieże i pobicia, ale także morderstwa, o których wielu rozmówców wspomina - czasem deklarując również graniczącą z obrzydzeniem niechęć do miejsc schadzek. ${ }^{13}$ Mężczyzna (lat 75) opowiada o tym, jak on i jego partner, z którym tworzyli otwarty związek, poznawali nowych znajomych i nowych seksualnych partnerów:

${ }^{13}$ Oczywiście istniała (i nadal istnieje) grupa mężczyzn nawiązujących głównie lub wyłącznie anonimowe kontakty seksualne z innymi mężczyznami, nieuczestniczących wcale w "gejowskim życiu”, o którym wspomina Stanely - do nich jednak nie dotarliśmy ze względu na specyfikę badanej próby, wyłonionej metodą kuli śnieżnej, czyli właśnie z polecenia. 
My prawie, że w ogóle nie chodziliśmy... nie istnieliśmy w knajpach. Tylko w prywatnych mieszkaniach. I to to oni... I tam zawsze coś było, i to było poza tym już pewna selekcja, no ludzi ciekawych. To nie było tak, że że... w knajpach to nie wiadomo było, co to tam jeden za jeden.

Mimo że anonimowy seks nie zniknął, zapoznawanie się i wynajdywanie potencjalnych partnerów na spotkaniach towarzyskich i dzięki pośrednictwu znajomych było ważnym elementem dyskursywnego i sieciowego charakteru społeczności homoseksualnej w latach 70. Akces do "gejowskiego życia", wówczas jeszcze tak nienazywanego, odbywał się na poziomie języka, a nie tylko zachowań seksualnych, w kręgu osób znajomych i poznawanych z polecenia, a nie tylko w sposób anonimowy.

Towarzyskie spotkania, o których wspomina Stanley, odbywające się w lokalach - liczni rozmówcy z Warszawy zaliczyli do nich bar w restauracji Ambasador w Alejach Ujazdowskich, kawiarnię Alhambra w Alejach Jerozolimskich i nadal istniejącą kawiarnię Amatorska przy Nowym Świecie - a także w prywatnych mieszkaniach, stanowiły specyficzną przestrzeń, w której można było eksperymentować z własną ekspresją płciową. W wywiadach pojawiają się wzmianki o przyjęciach, na których przebierano się $w$ damskie ubrania lub wykorzystywano codzienne przedmioty i elementy wyposażenia mieszkania do tworzenia zabawowych kostiumów. Mężczyzna (lat 80): „.... takim mieszkaniu, u cioci powiedzmy, można było, jak się towarzystwo już rozbawiło, napiło wódki czy wina, zdjąć firankę, nie wiem, ręcznik frotte, zrobić z niego jakiś turban, przypiąć do tego kwiaty i już powstawała jakaś niby kreacja". Towarzyskość i związany z nią kontekst zabawy - jak pisał o towarzyskości Georg Simmel dawała okazję do chwilowego odrzucenia codziennej roli społecznej i wypróbowania innych masek i kostiumów, których w trakcie zabawy nie trzeba było od razu przyjmować na serio, ale które rozszerzały repertuar autoekspresyjnych i relacyjnych możliwości. W tym sensie towarzyskość i skłonność ku uspołecznieniu („sociability” i „sociality” w przekładzie Everetta Hughesa) nie są od siebie odrębne. Towarzyskość jest zalążkiem społeczności i umożliwia jej prowizoryczną eksplorację.

Towarzyskość jako sposób zaistnienia społeczności homoseksualnej była elementem procesu werbalizacji i - szerzej - symbolicznej ekspresji homoseksualnej tożsamości. Pośrednio świadczą o tym silne przekonania niektórych rozmówców dotyczące stosowności lub niestosowności przebierania się za kobiety i „przeginania się". Mężczyzna (lat 75):

Jak my walczymy o uznanie [...], to powinniśmy pokazać całemu światu, że jesteśmy tacy sami jak reszta. I że zachowujemy się normalnie, wszędzie. Więc nie ma, nie ma powodu do zwalczania nas. [...] Więc takie było moje założenie w tym wszystkim, więc dlatego takiej... takich przegiętych ciot to... to... to nie. [...] Ja uważałem to za wstrętne. 
Nawet jeśli przytoczona opinia budzi sprzeciw jako nadmiernie normatywna lub wykluczająca, to jednoznacznie wskazuje na świadomość politycznego znaczenia sposobów autoprezentacji, a więc na autorefleksyjność dotyczącą posługiwania się symbolami - językiem, gestem, ubiorem. Podobna refleksja była charakterystyczna dla kultury gejowskiej za żelazną kurtyną. ${ }^{14}$

\section{Od społeczności do aktywizmu}

Sieciowy i dyskursywny charakter rodzącej się homoseksualnej społeczności okazał się kluczowy dla późniejszej działalności politycznej. W drugiej połowie lat 80. sieć nieformalnych kontaktów miała umożliwić samoorganizację społeczności lesbijsko-gejowskiej. Opowiadając o swoim uczestnictwie w rodzącym się Warszawskim Ruchu Homoseksualnym, rozmówca (ur. 1941) odnosi się krytycznie do spotkania, w którym uczestniczył, ponieważ przypominało zwykłe spotkanie towarzyskie: „Zboralski ściągnął, ściągnął towarzystwo do Warszawy i właściwie głównym, głównym tematem tego pierwszego spotkania było kto kogo przenocuje. Kto którego chłopaka weźmie do siebie na noc. [śmiech]" Jednak to właśnie sieć nieformalnych powiązań i dyskursywny charakter nawiązywanych kontaktów umożliwił podjęcie działań formalnych. Kiedy w latach 80. pojawiły się trzecioobiegowe publikacje o tematyce gejowskiej lub gejowsko-lesbijskiej, takie jak "Filo", ich dystrybucja także opierała się na osobistych kontaktach, a więc na sieciowym charakterze społeczności czytającej te pisma.

Inny rozmówca, który także brał udział w spotkaniach organizowanych przez Waldemara Zboralskiego w latach 1986-1987 „w jakiejś piwnicy na Sadybie”, a także w mieszkaniu przy ulicy Mianowskiego i w Domu Literatów na Starym Mieście, wspomina udział w tych spotkaniach dziennikarzy Mariusza Szczygła i (jednorazowo) Katarzyny Nazarewicz, a także innych kobiet: „Dziewczyny też były nasze, koleżankę, pamiętam [...], taka Renata była. Były dwie, przychodziły na te spotkania..." Udział kobiet w spotkaniach organizacyjnych, a zwłaszcza udział lesbijek („Dziewczyny też były nasze”) wskazuje na przejście od towarzyskiego do społecznościowego, czy wręcz politycznego charakteru podejmowanych działań. ${ }^{15}$ Jest to uderzająca różnica, ponieważ w relacjach z wcześniejszych spotkań o charakterze głównie towarzyskim rzadko pojawiają się wspomnienia o uczestniczących w nich kobietach, a jeśli już, to są to kobiety-przyjaciółki homoseksualnych mężczyzn, a nie lesbijki. Mężczyzna (lat 75): „Raczej, raczej nie lesbijki, ale jakieś jakieś dziewczyny były nie raz. [...] A spotkania też były no nie zawsze u gejów. Na przykład u Marysi Fołtyn. Ona była, ona uwielbiała mieć koło siebie, dookoła wyłącznie gejów".

\footnotetext{
${ }^{14}$ W latach 70. w Ameryce Północnej i na zachodzie Europy rozpowszechniła się subkuktura clones, czyli gejów kultywujących hipermęski wygląd, obejmująca zainteresowanie kulturystyką, noszenie zarostu, zwłaszcza wąsów, oraz typowo męskich ubrań, takich jak dżinsy, podkoszulki i skórzane kurtki - przytoczona opinia rozmówcy wpisuje się w analogiczny schemat męskiej homoseksualności promującej stereotypowo męskie zachowania i wygląd. Jednocześnie zatarciu ulegała pamięć o udziale kobiet oraz mężczyzn w kobiecym ubraniu w początkach ruchu gejowskiego, między innymi w starciach z policją przed barem Stonewall w Nowym Jorku latem 1969 roku. Zob. Duberman (1993).
}

15 Wiadomo także, że współpracowniczką „Filo" była Paulina Pilch, która jako młoda dziewczyna zainicjowała i redagowała rubrykę kobiecą. 


\section{Listy do Wiednia (zbiór HOSI Wien)}

Cennym źródłem wiedzy na temat mężczyzn homoseksualnych w Polsce i używanego przez nich języka jest zbiór listów przysłanych z Polski do wiedeńskiej Homosexuelle Initiative (HOSI) na początku lat 80. ${ }^{16}$ W 1976 roku na emigracji w Austrii znalazł się Andrzej Selerowicz, który został aktywistą HOSI Wien (HOSI funkcjonowały także w innych austriackich miastach). Jako przedstawiciel handlowy często jeździł służbowo do Polski, gdzie nawiązywał znajomości, wykorzystując i kształtując nieformalną sieć rodzącej się homoseksualnej społeczności. Informacja o HOSI Wien rozchodziła się pocztą pantoflową i pod jej adres trafiały listy od mężczyzn w Polsce, na które Selerowicz starał się odpisywać, posługując się własnym nazwiskiem lub pseudonimem Marek Jaworski. Część listów zawierała prośby o ułatwienie wyjazdu lub pomoc w nawiązaniu kontaktu z potencjalnymi partnerami za żelazną kurtyną. Proszono też o informacje o sytuacji osób homoseksualnych za granicą. Odpisując na te listy, Selerowicz/Jaworski prowadził w istocie kampanię informacyjną na temat homoseksualności, zwłaszcza że rosnąca liczba korespondentów wkrótce skłoniła go do odpowiadania przy pomocy napisanego na maszynie i mechanicznie powielonego gotowca, zaczynającego się od słów "Drogi Przyjacielu” i podpisywanego wspomnianym pseudonimem. Powielany list stał się kwartalnym „Biuletynem”, a potem zyskał tytuł „Etap”. Ukazywał się w latach 1983-1987. Kierujący wówczas wiedeńską HOSI Kurt Krickler polecił Selerowiczowi archiwizowanie nadchodzącej korespondencji, dzięki czemu jej zbiór jest dziś dostępny. Obejmuje kilkaset listów, w większości pisanych ręcznie przez osoby prywatne (właściwie wyłącznie przez mężczyzn), oficjalną korespondencję z instytucjami w Polsce oraz druki ulotne z Polski nadesłane w późniejszym okresie. ${ }^{17}$

Pewna część listów pochodzi od stałych korespondentów, często osobiście znanych Selerowiczowi. W tej grupie znajdują się współpracownicy pomagający rozprowadzać "Biuletyn" w Polsce, przekazujący go z rąk do rąk lub pocztą krajową. Listy od współpracowników dają wgląd w system dystrybucji, będący swoistym amalgamatem metod stosowanych w dystrybucji handlowej i zasad konspiracji. W 1985 roku współpracownik z Radomia sprawozdawał kontakty z odbiorcami "Biuletynu”, posługując się przypisanymi im numerami:

Serdeczne dzięki za list i biuletyny (w ilości 38). Zgodnie z życzeniem list czytał też nr 49. Otrzymaliśmy już kilka odpowiedzi od korespondentów. Otóż nr 7 został skreślony na własną prośbę. Skreśliliśmy też (po otrzymaniu listu) nr 3. Listy z wyrazami podziękowania przysłali 9, 22, 25, 28 i nowi nr 59, 60. Ciekawy list otrzymałem od nr 30 cytuję jego wypowiedź...

\footnotetext{
${ }^{16}$ Kurt Krickler i Anna Szut z HOSı Wien umożliwili mi skorzystanie ze zbioru listów z Polski w siedzibie tej organizacji (co miało miejsce 16 marca oraz 16 kwietnia 2018). Andrzej Selerowicz pomógł mi w zapoznaniu się z tym zbiorem, wyjaśnił okoliczności jego powstania i udostępnił kilka dodatkowych listów ze swojej prywatnej korespondencji.

17 Prawdopodobnie nie zachowały się najwcześniejsze nadesłane z Polski listy. Pierwsze listy kierowane do HOSI Wien przez nieznanych Selerowiczowi mężczyzn są datowane na rok 1983. Wcześniejsza korespondencja ma inny charakter - na rok 1982 datowany jest na przykład adresowany do Selerowicza list Grzegorza Musiała dotyczący planów przekładu jego powieści Stan płynny na język niemiecki.
} 
Listy od tego współpracownika zawierają także jego prywatne zwierzenia. Przenikanie się wątków organizacyjnych i osobistych, czasem intymnych, cechuje też korespondencję z innymi osobami. Listy ilustrują sieciowy charakter działalności prowadzonej przez Selerowicza i jego współpracowników, wskazując na wyłanianie się aktywizmu zorientowanego na dyskursywną autoprezentację homoseksualnej społeczności z kontaktów o charakterze towarzyskim.

Część korespondentów dobitnie wskazywało na milczenie wokół homoseksualności i jego stygmatyzujący charakter. Korespondent z Poznania pisał: „W Polsce sprawy o których piszesz są ściśle "tabu” i chociaż nie jest ścigane przez polskie ustawodawstwo, ich przeciwnicy są szykanowani a wręcz ośmieszani w środowisku (o ile się ujawnią)". Jednocześnie, mimo obowiązującej społecznej umowy milczenia, nadsyłane listy świadczą o jej przełamywaniu, między innymi przez innowacje leksykalne. Jedną z bardziej znaczących było zapożyczone z angielskiego słowo "gej”. Wspomniany korespondent z Radomia pisał: „Byliśmy też w tej gejowskiej kawiarence »Sezam « w Sopocie.” To nowe słowo pojawia się jednak rzadko i w latach 80. dopiero się upowszechnia. Jeden z piszących pytał wprost: „Chciałbym poinformować się w sprawie wielu problemów, które mnie nurtują, ale nie wiem czy mogę liczyć na odpowiedź z Pańskiej strony. Mianowicie co oznacza słowo »gej«."

W tym samym 1985 roku korespondent ze Stalowej Woli użył angielskiego słowa "gay" pisząc o przekładzie, który go zainteresował. (Korespondenci często wspominali o publikacjach prasowych, książkach, filmach i nielicznych programach telewizyjnych, w których poruszany był temat homoseksualności): „I jeszcze może o sprawie, która Ciebie może zainteresuje. Chodzi o publikacje na temat gay'ów (nie wiem czy tak się to pisze). Niedawno ukazała się książka T. Williamsa pt. Jednoręki". W nieco późniejszym liście Dariusz Prorok na dwóch stronach maszynopisu zaproponował odmianę rzeczownika "gej" i przymiotnika "gejowski". (Prorok pod koniec roku 1985 pod pseudonimem Krzysztof T. Darski opublikował w "Polityce” tekst "Jesteśmy inni”, uznawany za wczesny manifest społeczności homoseksualnej, w którym jednak nie użył słowa "gej”.) Sam Andrzej Selerowicz także przyczynił się do spopularyzowania i spolszczenia tego angielskiego słowa.

W listach wyraźnie widać deficyt określeń grupy osób o homoseksualnej samoidentyfikacji. W 1985 roku pisał mężczyzna ze Świętochłowic, który będąc w Krakowie przypadkowo znalazł czyjś portfel, a w nim „Biuletyn":

Biuletyn ten bardzo mnie zainteresował, gdyż jestem z tego samego kręgu, o którym Pan pisze. Na końcu biuletynu zaznaczył Pan, że kto chce otrzymywać podobne biuletyny powinien wysłać swój adres. Przyznam, że jakoś bardzo mi nieporęcznie [sic!] ingerować w ten sposób w Pana codzienność, lecz częściowo wiedziony instynktem ciekawości wreszcie przełamałem lody barier i stąd ten list.

Autor tego listu złożył zupełnie jasną deklarację swojej homoseksualności, posługując się jednak peryfrazą: „jestem z tego samego kręgu, o którym Pan pisze”. Również określenie „wiedziony instyn- 
ktem”, przez dobór słów wskazujące na seksualność, zostało złagodzone dopiskiem o „instykcie ciekawości". Powstaje wrażenie, że w tym nader elokwentnym liście zwrot "przełamałem lody barier" ściśle wiąże się z tęsknotą za językiem, którym można by mówić o homoseksualności, a który nie byłby "nieporęczny”. Użyte w liście słowo "krąg” nie przyjęło się jako synonim homoseksualnej społeczności (mimo analogii do niemieckiego słowa Kreis, używanego czasem do określenia grupy osób homoseksualnych). Funkcjonuje tu zresztą jako peryfraza, czy wręcz elipsa, analogicznie do innych określeń stosowanych przez homoseksualnych mężczyzn, które znamy z wywiadów - określeń w rodzaju "on jest taki", gdzie zamiast konkretnego terminu pojawia się ewentualnie nieokreślony gest ręki lub dwuznaczny uśmiech.

Niejednoznacznie brzmi dość często stosowany termin „środowisko”. Na przykład seksuolog Andrzej Jaczewski pisał do Selerowicza, którego znał osobiście (bez daty): „Aranżując czy inspirując wydawnictwa trzeba o tym pamiętać: czego innego oczekuje »środowisko « na własny użytek, czego innego trzeba dla powszechnego odbiorcy". Ta wypowiedź, dotycząca zamieszczania treści o charakerze pornograficznym w wydawnictwach krążących w odpisach i przeznaczonych dla homoseksualnych mężczyzn, wskazuje na świadomość strategii autoprezentacji homoseksualnej społeczności, a zwłaszcza na możliwy rozdźwięk między przedstawieniami kierowanymi na zewnątrz i tymi, które przeznaczone były na użytek homoseksualnych odbiorców. W tym samym liście słowo „środowisko” pojawia się aż pięciokrotnie, ale tylko raz w cudzysłowie. Ujęcie w cudzysłów miało zapewne podkreślić dwuznaczność tego określenia, kojarzącego się z półświatkiem - skojarzenie takie mogła podsunąć myśl o pornografii, wówczas nielegalnej. ${ }^{18}$

W liście z 1985 roku, nadesłanym z Warszawy i podpisanym przez parę mężczyzn, eksponowano potrzebę podjęcia działań o charakterze aktywistycznym, zaś samoidentyfikacja ze "środowiskiem” została zadeklarowana mimo rozczarowania jego apolitycznością:

Nie mamy żadnych informacji, jakoby ktokolwiek w kraju próbował prowadzić jakąkolwiek działalność na rzecz Gay-Lib. Może - nie wiem. Poznawszy w swym życiu wiele już osób - nie spodziewam się, aby to kogokolwiek interesowało. Daj Boże, bym się mylił i nie krzywdził tak bardzo środowiska (swego). [podkreślenie w oryginale]

Dodany w nawiasie zaimek osobowy "swego" pojawia się jakby po chwili refleksji, być może po przełamaniu wewnętrznego oporu. (Podobnie jak większość listów, ten także został napisany odręcznie, zaś ewentualna zmiana szyku słów zostałaby na papierze uwieczniona - stąd zapewne dopisek w nawiasie.) Również zmiana liczby mnogiej na pojedynczą („nie mamy” - „nie wiem”) nadaje tej

18 Określenie „środowisko” („środowisko homoseksualne”) było stosowane przez Milicję Obywatelską i inne służby, na co zwrócił mi uwagę Jerzy Krzyszpień w rozmowie przeprowadzonej 28 kwietnia 2017. 
wypowiedzi charakter nieomal osobistego świadectwa, domyślnie problematyzując przynależność do „środowiska” jako kwestię jednostkowego wyboru, wymagającego zarazem utożsamienia z grupą.

Sporadycznie występuje w listach słowo "mniejszość". Współpracownik nr 49 pisał w roku 1985: „Mam jeszcze swoich stałych 16 korespondentów z naszej mniejszości s.". Domyślamy się, że mowa tu o mniejszości seksualnej. Użycie słowa „mniejszość" może świadczyć o zmianie pokoleniowej (piszący to uczeń szkoły średniej), a także o świadomości językowej wynikającej z pewnej znajomości aktywizmu na rzecz lesbijek i gejów za żelazną kurtyną, chyba właśnie za sprawą "Biuletynu” i kontaktu z Selerowiczem. Słowo to pojawia się jednak rzadko.

Niektórzy korespondenci oczekiwali wyjaśnienia terminów związanych z zachowaniami seksualnymi, o których czytali w „Biuletynie”. W 1985 czytelnik z Katowic pytał: „W nawiązaniu do treści biuletynu prosiłbym o wyjaśnienie mi co oznaczają słowa »fellato« [sic!], »golden schower [sic!], »fistfucking«. Z drugiej strony w listach jest stosunkowo niewiele określeń używanych w homoseksualnym argocie lub pojawiają się one w kontekście krytycznym. W liście nadesłanym z Wrocławia w 1986 roku czytamy:

Chciałbym również, abyś zwrócił baczniejszą uwagę na stosowane w biuletynach słownictwo, np. "cioty tekstylne" itp. Jeżeli sami siebie będziemy przezywać od ciot to nie możemy mieć pretensji potem do heteroseksualistów, że czynią to samo. Dla mnie między słowem "ciota" a "pedał" a "zboczeniec" jest cienka granica.

Ta krytyczna uwaga skierowana pod adresem Selerowicza świadczy o tym, że niektórzy odbiorcy "Biuletynu" traktowali język jako polityczny oręż.

Traktowanie języka w kontekście walki o uznanie jest wyraźnie widoczne w listach nadsyłanych przez ówczesnych i późniejszych aktywistów - takich jak wspomniany już Dariusz Prorok. W jednym z listów w zbiorze HOSI Wien (datowanym na 28 października 1984), napisanym po niemiecku, dwudziestoczteroletni Waldemar Zboralski narzeka na powszechne w polszczyźnie słowo „pedał”, które "wywołuje u nas frustrację". ${ }^{19} \mathrm{~W}$ tym samym liście dopytuje, czy do HOSI Wien nadchodzą inne listy od chłopaków z Polski, czy może przekazać ten adres znajomym, i czy owi znajomi mogliby pisać po polsku. ${ }^{20}$ Wskazuje w ten sposób na sieciowy charakter wczesnego aktywizmu, jaki sam uprawia także na wagę przywiązywaną do potrzeby znalezienia słów odpowiednich do mówienia o homoseksualistach ("dieses Wort macht uns Verdruss"). ${ }^{21}$

19 "Und dieses Wort macht uns Verdruss".

20 "Wieviel Jungen aus Polen haben schon an Euch geschrieben, wie ich? Darf ich anderen meine Freunden Deinen Anschrift geben? Koennen meine Freunde an Dich auch in polnisch schreiben?"

${ }^{21} \mathrm{~W}$ zbiorze znajdują się dwa listy Zboralskiego napisane po niemiecku, zanim przeszedł na język polski. Kiedy pierwszy raz zwracał się do HOSI Wien, nie wiedział o „Biuletynie”. 
Treść listu Zboralskiego świadczy o autorefleksyjności dotyczącej używanego języka, a chęć rozpropagowania kontaktu do HOSI Wien wśród znajomych i troska o otwarcie kanałów komunikacyjnych ilustruje sieciowy i dyskursywny charakter społeczności, którą współtworzył. Zamiar skontaktowania znajomych z organizacją zrzeszającą osoby homoseksualne podkreśla bliski związek między towarzyskością a aktywizmem - w późniejszej działalności Zboralski nadal realizował ten schemat, przekuwając relacje prywatne $\mathrm{w}$ działalność publiczną i polityczną.

\section{Konkluzja}

W trakcie "długich latach 70." homoseksualność stała się tworem dyskursywnym - hasłem mobilizującym ludzi nieznających się osobiście. Zaczęła funkcjonować w językowym obiegu, wytwarzając sieć powiązań realizowanych w sferze symbolicznej, a nieopartych jedynie na bezpośrednim kontakcie, jak miało to miejsce w nieformalnych instytucjach funkcjonujących w przestrzeni miejskiej i umożliwiających nawiązanie relacji seksualnej. Obieg informacji, również tej przekazywanej w codziennych rozmowach, powodował stopniową erozję niepisanej umowy milczenia na temat homoseksualności, mimo że pewien stopień tabuizacji, związanej ze społecznym napiętnowaniem i odczuwanym wstydem, utrzymywał się (i występuje nadal) między innymi w rodzinach pochodzenia.

Przemiana ta częściowo odpowiadała analogicznym procesom następującym w tych samych latach w niektórych krajach Europy Zachodniej i Ameryki Północnej. Różnica wynikała z ograniczeń rozwoju społeczeństwa obywatelskiego w ustroju zdominowanym przez jedną partię polityczną i związanego z tym deficytu demokracji. Rolę kontaktów towarzyskich w polskim kontekście można rozumieć jako kompensację niemożności stworzenia szerszego ruchu, który mógłby swobodnie ogłaszać swoje cele i pozyskiwać członków i sprzymierzeńców. Jednocześnie rozszerzanie sieci kontaktów było dostępnym, choć niepełnym remedium na ten deficyt i faktycznie doprowadziło do powstania ruchu dążącego do sformalizowania jeszcze przed 1989 rokiem. Wczesne formy samoorganizacji homoseksualnej społeczności w latach 80. wykorzystywały istniejące uprzednio relacje o charakterze towarzyskim i wyrastały na ich gruncie. Dlatego sieciowy i dyskursywny charakter tej powstającej społeczności, wyprzedzający ściśle polityczne działania, należy określić mianem protopolityczności.

\section{Podziękowania}

Artykuł powstał w ramach projektu "Cruising the 1970s: Unearthing Pre-HIV/AIDS Queer Sexual Cultures" (CRUSEV) finansowanego ze środków HERA Joint Research Programme 3 "Uses of the Past" przy współfinansowaniu ze strony AHRC, BMBF via DLR-PT, MINECO, NCN oraz Komisji Europejskiej w ramach programu Horizon 2020. Dziękuję Agnieszce Wiciak i Adrianie Kapale ze Stowarzyszenia Lambda Warszawa za udostępnienie nagrań z Johnem Stanleym i Elżbietą Parczewską, Krzysztofowi Kliszczyńskiemu za umożliwienie kontaktu z uczestnikami Grupy Senioralnej w Lambdzie, Andrzejowi Selerowiczowi za ułatwienie dostępu do archiwum HOSI Wien i za wyjaśnienie okoliczności jego powstania, Kurtowi Kricklerowi i Annie Szut z HOSI Wien za udostępnienie tego zbioru, a Jerzemu 
Krzyszpieniowi za rozmowy o projekcie. Dziękuję koleżankom i kolegom z zespołu CRUSEV za liczne rozmowy, cenne pomysły, wskazówki i uwagi - Agnieszce Kościańskiej także za wskazanie cytatu z „itd", Krzysztofowi Zabłockiemu za umówienie i współprowadzenie większości przytoczonych tu wywiadów i Jędrzejowi Burszcie za uważną lekturę tego artykułu. Przede wszystkim jednak dziękuję wszystkim, którzy zdecydowali się na udzielenie wywiadu.

\section{Bibliografia}

Basiuk, Tomasz. 2013. Exposures. American Gay Men's Life Writing since Stonewall. Frankfurt am Main: Peter Lang Verlag.

Chauncey, George. 1994. Gay New York. Gender, Urban Culture, and the Making of the Gay Male World, 1890-1940. New York: Basic Books.

Darski, Krzysztof T. (właśc. Dariusz Prorok). 1985. Jesteśmy inni. W: "Polityka" 85.

Delany, Samuel R. 2004 (1988). The Motion of Light in Water. Sex and Science Fiction Writing in the East Village. Minneapolis: University of Minnesota Press.

Duberman, Martin. (1993). Stonewall. Nowy Jork: Plume.

Fiedotow, Agata. 2012. Początki ruchu gejowskiego w Polsce (1981-1990). W: (red.) Kula, Marcin. Kłopoty z seksem w PRL. Rodzenie nie catkiem po ludzku, aborcja, choroby, odmienności. Warszawa: Wyd. Uniwersytetu Warszawskiego.

Foucault, Michel. 1986 (1984). Of Other Spaces. Ttum. Jay Miskowiec. W: "Diacritics" 16 (1) Spring 1986, s. 22-27.

Gorgol, Tadeusz. 1974. Homoseksualizm a opinia. W: "Życie Literackie", 28.04.1974.

Hall, Dorota. 2016. W poszukiwaniu miejsca. Chrześcijanie LGBT w Polsce. Warszawa: IFiS PAN.

Humphreys, Laud. 2007 (1970). Tearoom Trade. Impersonal Sex in Public Places. New Brunswick and London: Aldine Transaction.

Jagielski, Sebastian. 2013. Maskarady męskości. Pragnienie homospołeczne w polskim kinie fabularnym, Kraków: Universitas.

Krzyszpień, Jerzy. 2018. Wychodzimy z ukrycia. Ujawnianie się lesbijek, gejów, biseksualnych i transptciowych+. Kraków: Korporacja Ha!art.

Lew-Starowicz, Zbigniew. 1973a. Listy do seksuologa. W: „itd” 9, s. 20.

Lew-Starowicz, Zbigniew. 1973b. Listy do seksuaologa (2). W: „itd” 10, s. 20.

Pedemokracja czyli Btękitna mitość. W: „Forum” 281 (34) 26.08.1970, s. 20. (Przedruk z “Le Crapouillot").

Rich, Adrianne. 1980. Compulsory Heterosexuality and Lesbian Existence. W: „Signs. Journal of Women in Culture and Society" 5 (4), s. 631-660.

Ritz, German. 2002. Nić w labiryncie pożądania: gender i pteć w literaturze polskiej od romantyzmu do modernizmu. Tłum. A. Kopacki, M. Łukasiewicz, B. Drąg. Warszawa: Wiedza Powszechna. 
Rogulska, Paulina. 2006. Miniprzewodnik po Wrocławiu z "Lubiewa" Michała Witkowskiego. W: "InterAlia" 1.

http://interalia.org.pl/pl/artykuly/2006_1/13_bardzo_mini_przewodnik_po_wroclawiu_z_lubiewa _michala_witkowskiego.htm

Sadowska, Małgorzata i Bartosz Żurawiecki. 2006. Barwy ochronne, czyli kino seksualnego niepokoju. W: (red) Basiuk, T., D. Ferens, T. Sikora. Parametry pożądania: kultura odmieńców wobec homofobii. Kraków: Universitas, s. 153-160.

Schulman, Sarah. 2009. Ties That Bind. Familial Homophobia and Its Consequences. Nowy Jork: The New Press.

Simmel, Georg. 1949. The Sociology of Sociability. Tłum. Everett C. Hughes. W: "American Journal of Sociology" 55 (3), s. 254-261.

Stryjkowski, Julian. 1993. Milczenie. Kraków: Wydawnictwo Literackie.

Szulc, Łukasz. 2018. Transnational Homosexuals in Communist Poland. Cross-Border Flows in Gay and Lesbian Magazines. Palgrave.

Tomasik, Krzysztof, Zabłocki, Krzysztof, Piet, Marcin. 2009. HomoWarszawa. Przewodnik kulturalnohistoryczny. Warszawa: Abiekt.pl.

Tomasik, 2018 (2012). Gejerel. Mniejszości seksualne w PRL-u. Warszawa: Krytyka Polityczna.

Warkocki, Błażej. 2007. Homo niewiadomo. Polska proza wobec odmienności. Warszawa:

Wydawnictwo Sic!.

Zabrzeski, Wojciech. 1966. Homoseksualizm: grzech czy przestępstwo? "Prawo i życie”, 13.01.1966.

From an unspoken pact of silence to the protopolitical: discursive homosexual networks in the 'long $1970 s^{\prime}$ as reflected in oral history and epistolography

During "the long 1970s" in Poland homosexuality began to be thematized in public and semi-public discourse, enabling a sense of community among people who were not personally acquainted. The discursive emergence of homosexuality was gradually eroding an unspoken pact of silence which had prevailed before. Early selforganizing relied heavily on private networking, in which forms of proto-political sociality supported and enabled the emergence of properly political activism. The paper draws on oral history interviews and on letters which men in Poland sent to the Austrian organization HOSI Wien in the mid-1980s.

Keywords: proto-political, networking, discursivity, oral history, epistolography, queer, LGBT past in Poland 